\title{
The High Cost of US Immigration Policy: Putting US Agriculture at Risk
}

\author{
Zepeda Lydia* \\ Department of Consumer Science, USA \\ *Corresponding author: Zepeda Lydia, Department of Consumer Science, USA \\ Submission: 㘹January 22, 2018; Published: 海 February 06, 2018
}

Abbreviations: ICE: Immigration and Customs Enforcement; DHS: Department of Homeland Security; CCA: Corrections Corporation of America

\section{Opinion}

The US food system depends on immigrant workers from farm to fork. They work as milkers and cheese makers, in the poultry industry, in slaughterhouses, food processing, food service, and hospitality. Within US agriculture, an estimated $71 \%$ of workers are immigrants and $95 \%$ of those immigrants are from Mexico. Farmers and business owners say they hire immigrants because they are unable to find American workers.

Many of those immigrant workers are undocumented, and US agriculture relies disproportionately on them. While only $5 \%$ of the US workforce is undocumented, it is estimated that about half the agricultural workers in the US are undocumented. These immigrants are concentrated in six states with large agricultural sectors; 59\% live in California, Texas, Florida, New York, New Jersey and Illinois. Nearly two-thirds have lived in the US for more than ten years and half are from Mexico. Current US policies make undocumented workers much less expensive than legal immigrants. Take milkers in the dairy state as an example. In 2015, Wisconsin milkers made between $\$ 8.25$ and $\$ 9.75$ per hour, well below the minimum wage mandated for a legal immigrant with an H2A visa: $\$ 11.56$ per hour. Only $500 \mathrm{H} 2 \mathrm{~A}$ visas were issued for the 76,400 agricultural workers in the state. Given that approximately half of the dairy workforce was undocumented, hiring undocumented immigrant rather than legal immigrants with visas saved Wisconsin farmers an estimated \$185 million in 2015. The economic incentives to hire undocumented workers are clear.

While it is illegal to hire undocumented workers and can result in civil fines and criminal penalties if there is a pattern or practice of doing so, employers are rarely punished. US Immigration and Customs Enforcement (ICE) often issues warnings rather than fines to employers. Further, when it does impose fines ICE reduces them by an average of $40 \%$ through negotiations. Given the cost savings and low probability of being punished, it is no wonder that US farmers rely on undocumented workers. However, record high deportations and record low border crossings are making it increasingly difficult to find workers. US border crossings are at a 45-year low; in FY2015, the US Border Patrol apprehended only 337,000 people.

This is less than $10 \%$ of the flow of legal temporary workers; that same year, the US government granted 3.7 million visas to temporary workers and their families. In addition, US deportations, stable at 40,000 per year throughout most of the 20th century, increased dramatically after the US Congress changed the laws in 1996 to allow expedited removals (deportations without a court order). In 2009, nine years into a dramatic decline in border crossings and despite Department of Homeland Security (DHS) data that showed that the unauthorized immigrant population was falling, Senator Robert Byrd (D-WV), inserted a detention mandate, requiring ICE maintain 33,400 detention beds. With border crossings at record lows, this bed quota effectively increased deportations of undocumented immigrants from the US interior. These deportations tended to be people living in the US for more than ten years. The increase in deportations meant that more people were deported from the US between 1997 and 2015 than were deported in all years prior to 1997.

The official story is that ICE is deporting criminals. However, using ICE's own statistics, the only crime committed by $85 \%$ of the immigrants removed or detained was entering the US without inspection, a civil offense. Of the 450,954 removals and detentions in FY2016, less than $2 \%$ can be classified as dangerous: $0.18 \%$ was suspected of being a national security threat and $1.8 \%$ had committed an aggravated felony. The cost of these policies is staggering. Using Border Patrol's budget, in FY2015 it cost \$11,266 per immigrant apprehended at the border. This is 50 times what is 
in FY1990 when it cost $\$ 224$ per border apprehension. Detention costs are also high; DHS estimates it spends \$126/day/bed for an adult in detention pending deportation and $\$ 161 /$ day/bed for family detention. Most are held in for-profit prison. In 2016, 65\% of those detained by ICE were held in private for-profit prisons. As an example, DHS announced in August 2016 a no-bid, four-year, \$1 billion contract with private contractor Corrections Corporation of America (CCA) for immigration detention. Under this contract, CCA receives $\$ 20$ million a month whether any of the 2,400 beds are occupied.

In June 2017 the facility had only 600 occupants, meaning DHS paid \$1,111 per person per night. DHS also pays private corporations to monitor immigrants released pending their immigration court hearings. In FY2017 DHS asked for \$126 million to pay a private company $\$ 6.50$ a day for 53,000 ankle monitors. The need for this expense is questionable; without electronic monitors, the compliance rate of immigrants showing up to their hearings is $98 \%$. These immigrants have every reason to appear at immigration hearings; the alternative means they have violated the terms of

Creative Commons Attribution 4.0

International License

For possible submission use the below is the URL Submit Article their release and could be deported. These aggressive deportation policies have made undocumented workers fearful, particularly workers from Mexico, who make up $80 \%$ of those being deported. Many workers restrict their movements, knowing that any traffic stop can lead to being turned over to ICE for deportation. It isn't just the workers and their families who are affected; farmers are finding workers who have been with them for years have disappeared overnight. Replacing these workers has become difficult due to US immigration policies.

US immigration policy makes it relatively easy to hire immigrants with technology expertise, yet US agriculture relies much more heavily on immigrants than IT. The prevalence of undocumented workers in agriculture makes them an easy target for ICE to deport. Reducing or repealing the bed quota could minimize adverse impacts to farm labor. However, reducing or eliminating the bed quota will still leave farmers and agricultural workers at risk because they will be violating immigration laws. To fix farm labor problems, US immigration policies need to be modified to allow farmers to hire the workers they need legally.

\section{Your subsequent submission with Crimson Publishers will attain the below benefits}

- High-level peer review and editorial services

- Freely accessible online immediately upon publication

- Authors retain the copyright to their work

- Licensing it under a Creative Commons license

- Visibility through different online platforms

- Global attainment for your research

- Article availability in different formats (Pdf, E-pub, Full Text)

- Endless customer service

- Reasonable Membership services

- Reprints availability upon request

- One step article tracking system 